\title{
Sociodemographic status of rape victims in Dhaka Metropolitan area
}

\author{
PK Bose ${ }^{1 凶}$, M Ara $^{2}$, MS Rahaman ${ }^{3}$, MZ Kabir $^{4}$, N Sultana $^{5}$, P Biswas $^{6}$, MAA Masud $^{7}$
}

\begin{abstract}
Our objective of the study was to find out the victims of common age group with relation to their educational and social status to set up a local and national policy to create nationwide awareness and taking necessary steps to stop this heinous crime. This is a cross-sectional descriptive type of study which was done in the Department of Forensic Medicine, Dhaka Medical College from January 2016 to December 2016 with maintaining ethical issues. A total of 69 cases, from 23 police stations of Dhaka Metropolitan area, were sent for a medicolegal opinion regarding forceful sexual intercourse and victims who ultimately agreed to do medicolegal examinations were examined and opinion was given, whether the signs of forceful sexual intercourse were present or not. Our study shows that female of $>10-\geq 20$ years of age group were the main victims and $69.6 \%$ of the victims belong to this age group followed by $14.5 \%$ with $>20-\geq 30$ years of age. Majority of the victims, $68.1 \%$ were from lower socioeconomic status. Educational knowledge of the victims was poor; $31.9 \%$ victims had the primary level of education, $24.6 \%$ were completely illiterate followed by $37.7 \%$ of victims had the education level as secondary and higher secondary, and $5.8 \%$ had the above higher secondary level. Victims of rape lead to very painful lives. They are just the victims of this heinous and supposed to get sympathy and empathy from the family, society, and state. But unfortunately, the victims of rape do not get proper attention from them. Sometimes victims are blamed by their surroundings. As a result, many victims commit suicide following rape. So, it should be addressed properly.
\end{abstract}

Keywords: sociodemographic status, rape, sexual assault, victim, medicolegal.

\section{Introduction}

Rape is such a crime which cannot be demonstrated easily. It destroys the morality and hope of a victim and creates disappointment and anger in the mind of a victim. Sometimes the victim is treated as a characterless female and thus may be socially isolated after rape. As a result, a female just loses her self-confidence, feels frustrated and may commit suicide. In warfare, females are specially targeted and raped. So, rape is not only a social crime but may be treated as a crime against humanity.

The word 'rape' is derived from Latin term 'rapio' which means to seize. Thus rape literally implies forcible seizure. ${ }^{1}$ Rape is defined as physically forced or otherwise

1. PK Bose, Asso. Prof. of Forensic Medicine, Enam Medical College, Savar. Email: palashbose223@ hotmail.com

2. M Ara, Lecturer, Department of Forensic Medicine, Dhaka Medical College.

3. MS Rahaman, Asst. Prof. of Forensic Medicine, Enam Medical College, Savar

4. MZ Kabir, Asso. Prof., Tairunnessa Memorial Medical College, Gazipur

5. N Sultana, Asso. Prof., ZH Sikder Women's Medical College, Dhaka

6. P Biswas, Lecturer, Dhaka Medical College, Dhaka

7. MAA Masud, Asso. Prof. of Pharmacology and Therapeutics, Kumudini Womens Medical College, Tangail 
coerced penetration, even if slight of the vulva or anus, using a penis, other body parts or an object. The attempt to do so is known as attempted rape. ${ }^{2}$

There is no age limit either for the victims or for the accused. It is the duty of the court to take an appropriate decision whether a young accused can be considered as sexually potent or capable or not. ${ }^{3}$ Children are more frequently raped than adults as they cannot offer much resistance and also due to a false belief that venereal diseases are cured by sexual intercourse with a virgin. Rape can be committed even when there is an inability to produce a penile erection. Rape can be occurred without causing any injury and such negative findings do not exclude rape. ${ }^{4}$ As a result, the slightest penetration of the penis within the vulva such as the minimal passage of glans (tip) between the labia with or without emission of semen or rupture of the hymen is also considered as rape. ${ }^{5}$ So, the examining doctor should mention the negative facts and should not say whether rape has not been occurred or not. ${ }^{4}$

\section{Materials and Method}

This is a cross-sectional descriptive type of study conducted in the Department of Forensic Medicine, Dhaka Medical College from January 2016 to December 2016 with maintaining ethical issues. Total 69 cases, who agreed to do medicolegal examinations, were recorded as victims of alleged sexual assaults. Victims of alleged rape cases from 23 Metropolitan police stations of Dhaka, were sent for medicolegal examinations within the above mention period. After the physical examination, radiological report and microbiological report, opinion was given whether the signs of forceful sexual intercourse were present or not.

\section{Results}

Table 1 shows that $69.6 \%$ of the victims belonged to $>10-\geq 20$ years of age group followed by $>20-\geq 30$ years of age yielding $14.5 \%$. Table 2 shows that the proportion of victims came from lower socioeconomic status, lower middle class and upper middle class were $68.1 \%, 26.1 \%$, and $5.8 \%$, respectively. Table 3 shows that $37.7 \%$ of the victims had the knowledge of secondary and higher secondary education followed by $31.9 \%$ with primary education and $5.8 \%$ with higher education level. But $24.6 \%$ victims were completely illiterate.

Table 1. Age variation of the rape victims, number $=69$

\begin{tabular}{lrr}
\hline Age in years & Number & $\%$ \\
\hline$\leq 10$ & 8 & 11.6 \\
$>10-\leq 20$ & 48 & 69.6 \\
$>20-\leq 30$ & 10 & 14.5 \\
$>30$ & 3 & 4.3 \\
\hline Total & $\mathbf{6 9}$ & $\mathbf{1 0 0 . 0}$ \\
\hline
\end{tabular}

Table 2. Socioeconomic status of the rape victims, number $=69$

\begin{tabular}{llrr}
\hline $\begin{array}{l}\text { Income } \\
\text { Taka/month }\end{array}$ & Status & Number & $\%$ \\
\hline$\leq 5000$ & Lower socioeconomic & 47 & 68.1 \\
$>500-\leq 15000$ & Lower middle class & 18 & 26.1 \\
$>15000$ & Upper middle class & 4 & 5.8 \\
\hline Total & & $\mathbf{6 9}$ & $\mathbf{1 0 0 . 0}$ \\
\hline
\end{tabular}

Table 3. Educational status of the rape victims, number $=69$

\begin{tabular}{lrr}
\hline Level of education & Number & \% \\
\hline Illiterate & 17 & 24.6 \\
Primary & 22 & 31.9 \\
Secondary and higher secondary & 26 & 37.7 \\
Above & 4 & 5.8 \\
\hline Total & $\mathbf{6 9}$ & $\mathbf{1 0 0 . 0}$ \\
\hline
\end{tabular}


Discussion

Around 120 million girls worldwide (slightly more than 1 in 10) have experienced forced intercourse or other forceful sexual acts at some point in their lives. ${ }^{6}$

In 2002, a study conducted in New Delhi found that $92.0 \%$ of women reported to have experience of some term of verbal sexual harassment (including unwelcome comments of sexual nature, whistling, leering or making obscene gesture) in their lifetime. ${ }^{7}$ In a study including over 24000 women, the World Health Organization found the following rates of women reporting forced sexual initiation such as $30.0 \%$ in rural area of Bangladesh, $24.0 \%$ in a city of Bangladesh, $24.0 \%$ in rural area of Peru, $7.0 \%$ in a city of Peru, $17.0 \%$ in an Ethiopian rural area, $4.0 \%$ in a city of Thailand, $3.0 \%$ in a city of Brazil, $7.0 \%$ in Serbia and Montenegro and $4.0 \%$ in a city of Japan. In all these, except Ethiopia, the younger the women were at the time of her first sexual experience, the more likely it was a forced sexual initiation. ${ }^{8}$

The magnitude of rape or sexual harassment is high all over the world. But it comes a little in front of us. In the majority of countries with available data; less than $40.0 \%$ of the women who experienced violence seek the help of any sort. Among who do, most informed to family and friends and very few look to formal institutions and mechanisms, such as police and health services. Less than $10.0 \%$ of those women seek no help by appealing to the police. ${ }^{9}$ The underreporting of cases of sexual assaults are mainly due to social stigma; prejudice in regard to chances of marriage, publicity in the press, embarrassment in court, doubt in local law enforcement, a risk of losing the love, respect of society, etc. ${ }^{10}$

In our study, we found that age of majority of the victims was $>10-\geq 20$ years followed by $>20-\geq 30$ years of age. Among the victims, $31.9 \%$ had the primary level of education followed by $24.6 \%$ victims were totally illiterate. Majority of the victims (68.1\%) were from lower socio-economic status. The findings are almost similar to some other studies with respect to the age and social status of the victims. ${ }^{11,13}$ In those studies, the age of majority $(70.0 \%)$ victims ranged from 11 to 20 years followed by 21 to 30 years of age $(11.0 \%) ; 29.0 \%$ of the victims were illiterate followed by $32.0 \%$ had the primary level of education. They were mostly $(77.0 \%)$ from lower socioeconomic class.

Saha et al showed that almost $80.0 \%$ victims were from 11 to 20 years of age followed by 21 to 30 years of age, $12.0 \% .^{12}$ they reported that majority (almost $85 \%$ ) of the victims were illiterate. This finding is not consistent with our findings and others. ${ }^{11}$ They also found that $83.0 \%$ of the victims were from lower socioeconomic class. Ali et al also reported majority (almost $60.0 \%$ ) of the victims' age were between 11 and 20 years followed by 21 to 30 years of age, $20.0 \% .{ }^{13}$ Ain o Salish Kendra, Bangladesh mentioned that in 2016 total 724 cases of rape victims were reported to different daily newspapers in Bangladesh. They studied and showed that $35.0 \%$ of the age of the victims ranged from 13 to 18 years followed by $33.0 \%$ aged $\leq 12$ years. ${ }^{14}$ The findings reported by Islam et al are similar to our study findings. ${ }^{15}$

\section{Limitation of the study}

This study was conducted in Dhaka Metropolitan area. Only $25.0 \%$ of police stations reported rape case in the Department of Forensic Medicine, Dhaka Medical College for medicolegal examination and opinion. So, these findings may not give us the exact pictures of rape victims in our country. Therefore, study with a larger sample is needed to find out the overall scenario regarding the issue.

\section{Conclusion}

The present study showed that the majority of the victims were from $>10-\geq 20$ years of age; $68.1 \%$ of the victims belonged to lower socio-economic status. The majority of victims were literate. Only $24.6 \%$ of the victims were illiterate. The victims of rape lead to very painful lives. They are just the victims of this heinous and supposed to get sympathy and empathy from the family, soci- 
ety, and state. But unfortunately, the victims of rape do not get proper attention from them. Sometimes victims are blamed by their surroundings. As a result, many victims commit suicide following rape. So it should be addressed properly.

\section{References}

1. Vij K. Medicolegal examination of the living. In: Textbook of Forensic Medicine and Toxicology: Principles and Practice, 6th ed. Reed Elsevier Pvt. Ltd: New Delhi, 2014.

2. World Health Organization (WHO). Sexual Offences. WHO, 2002. Available from http://www.who.int/violence_injury_preve ntion/violence/global_campaign/.../chap6. pdf (Accessed on January, 2018).

3. Nandy A. Sexual offences and sex perversions. In: Principles of Forensic Medicine Including Toxicology. New Central Book Agency: Kolkata, 2014.

4. Reddy KSN, Murty OP. Sexual offence. In: The Essentials of Forensic Medicine and Toxicology, 33rd ed. Jaypee Brothers Medical Publishers: New Delhi, 2014.

5. Shepherd R. Sexual offences. In: Simpson's Forensic Medicine,12th ed. Arnold: London, 2003.

6. UNICEF. Hidden in plain sight: a statistical analysis of violence against children. 2014. Available from https://www.unicef. org/publications/index_74865.html (Accessed on January, 2018).

7. UN WOMEN. Facts and figures: ending violence against women, 2012. Available from https://www.unwomen.org/en/whatwe-do/ending-violence-against-women/fa cts-and-figures (Accessed on January, 2018).

8. World Health Organization (WHO): WHO multi-country study on women's health and domestic violence against women. Available from http://www.who.int/iris/ handle/10665/43310 (Accessed on January, 2018).

9. United Nations Economic and Social Affairs. The world's women: Trends and Statistics, 2015. Available from http:// www.unwomen.org/en/what-we-do/endin g-violence-against-women/facts-and-figur es (Accessed on January, 2018).

10. Malhotra N, Sood M. Sexual assault, a neglected public health problem in developed world. Int J Obstet Gynaecol 2000;71(3):257-8.

11.Al-Azad MAS, Rahman Z, Ahmad M, Wahab MA, Ali M, Khalil MI. Sociodemographic characteristics of alleged sexual assault (rape) cases in Dhaka City. JAFMC Bangladesh 2011;7(2):21-4.

12.Saha KP, Rahman M, Mahmud S, Monsur A, Chakrabarty PK. Medicolegal aspect of rape.TAJ 2009;22(1):111-4.

13.Ali N, Akhter S, Hossain N, Khan NT. Rape in rural Bangladesh. Delta Med Col J 2015;3(1):31-5.

14. Ain o Salish Kendra, Bangladesh. Violence against women; rape. JanuaryDecember, 2016. 2017.

15.Islam MN, Islam MN. Retrospective study of alleged rape victims attended at Forensic Medicine Department of Dhaka Medical College, Bangladesh. Legal Medicine (Tokyo) 2003;5(1):351-3.

\section{Suggestion for citation of the above:}

Bose PK, Ara M, Rahaman MS, Kabir MZ, Sultana N, Biswas P, MAA Masud MAA. Sociodemographic status of rape victims in Dhaka Metropolitan area. Mediscope 2018;5(2):8-11. 